\title{
Egyptian Millennial Travellers' Willingness to Adopt and Use Travel Chatbots: An Exploratory Study
}

\section{Radwa Ali Hamed}

Tourism Studies Department, Faculty of Tourism and Hotels, Alexandria University

\begin{tabular}{l}
\hline ARTICLE INFO \\
\hline Keywords: \\
Artificial \\
intelligence; \\
Chatbots; \\
Millennials; Travel; \\
COVID-19.
\end{tabular}

(JAAUTH) Vol. 21, No. 1, (December 2021), PP.49-69.

\section{ABSTRACT}

Purpose - This research study focuses on investigating travel chatbots adoption among Egyptian millennial travellers. The study thus attempts to find out Egyptian millennial travellers' motives for using travel chatbots, their perceptions of risks, and future use intention.

Design/Methodology/Approach - An online questionnaire was developed to assess motives for using travel chatbots, perceived risks, and use intention based on several previous qualitative research studies. The survey was directed to Egyptian millennial travellers $(\mathrm{N}=241)$ and distributed via Facebook and WhatsApp.

Findings - The two strongest motivations for adopting travel chatbots among respondents were productivity followed by curiosity. Though chatbot users did not perceive travel chatbots as risky, non-users perceived them as risky in terms of privacy and global AI-related risks. Nevertheless, both chatbot users and non-users exhibited a positive attitude towards future use intention.

Practical implication - The results of this study provide travel and tourism businesses in Egypt with an understanding of millennial travellers' motives and behavioural intention to adopt new technologies such as travel chatbots. Such understanding would help businesses design and deliver quality online tourism experiences to their customers.

Originality/Value - There is quite a sufficient number of studies focusing on chatbots and AI-powered conversational agents, however, research on the motives for using travel chatbots is still scarce. No previous studies discussing travel chatbots adoption among Millennials were conducted in Egypt. Thus, the study contributes to academia as it adds to the scarce research on Egyptian Millennials' travel technology use behaviour.

\section{Introduction}

The COVID-19 crisis has brought about significant changes in consumer behaviour and preferences and has resulted in an unprecedented increase in the usage of digital services, which forced businesses to shift their offline traditional business models and 
adapt to new changes by digitizing their products and services to improve their customers' experiences (Lund, 2020; Sharma, 2020).

COVID-19 pandemic has noticeably catalyzed organizations' digital transformation (Dell Technologies, 2020; Deloitte, 2020). Globally, 70 per cent of businesses plan to either increase or maintain their spending on digital transformation despite the economic downturn resulting from the ongoing COVID-19 pandemic (IFS, 2020).

Artificial intelligence (AI) is an integral part of the digital transformation strategy (Calp, 2020). The adoption of Artificial Intelligence has grown exponentially amid the Covid-19 pandemic (Relx, 2020) as businesses are increasingly implementing AIdriven technologies to automate their processes, provide seamless communications, improve efficiency, reduce operational costs, and make informed business decisions (Sharma, 2020).

Today, AI-powered chatbots are becoming increasingly prevalent (Io and Lee, 2018). They are widely applied across various sectors (Frankenfield, 2020) such as healthcare, banking, education, entertainment, travel, and hospitality. Many businesses have deployed chatbots on the Internet to enhance customer service, answer FAQs, and help customers in their information-seeking process (Valtolina et al., 2018).

The global chatbot market size accounted for USD 1.17 billion in 2018 (Reports and Data, 2019) and is projected to exceed USD 17 billion by the year 2025 at a CAGR of 30 per cent (Adroit Market Research, 2020) as lots of businesses worldwide turned to chatbots to respond to the unprecedented surge in customers' requests and queries amid the pandemic. For example, many travel and tourism companies managed to respond to thousands of travellers' queries about cancellations and refunds using chatbots that would have been otherwise impossible to handle (Rodríguez, 2020).

To date there are no available statistics on chatbots usage in Egypt, however, a sudden rise in Arabic chatbot construction requests was reported during the first half of the year 2020, which represents a 100 per cent increase when compared to the figures for the whole of 2019 (Moneim, 2020). This huge increase in demand is attributed to the COVID-19 pandemic, which resulted in more businesses searching for new digital solutions to interact with their customers and maintain strong relationships with them by creating seamless personalised experiences while limiting direct human interaction (Gupta, 2020; Waldron and Wetherbe, 2020).

Nowadays most people seem to prefer texting over calling or sending emails (Battestini et al., 2010) especially Millennials who communicate almost entirely through chatting (Howe, 2015). Therefore, chatbots appear as an ideal communication channel for the travel and tourism businesses in Egypt to reach their potential customers.

Developing new interactive technologies such as travel chatbots requires a better understanding of users' motivations, attitudes, and intentions (Brandtzaeg and Følstad, 2017; Malhotra et al., 2008). Nevertheless, there is a lack of research on travel chatbots adoption in Egypt. Thus, this research study tries to fill a gap in travel 
chatbots literature by investigating travel chatbots adoption among Egyptian millennial travellers and examining their motives for using travel chatbots. Therefore, the main research questions can be stated as follows:

(1) What motivates or could motivate Egyptian Millennial travellers to use travel chatbots?

(2) Do Egyptian Millennial travellers trust travel chatbots or perceive them as risky?

(3) Are Egyptian Millennial travellers willing to adopt and use travel chatbots in the future?

\section{Literature review}

\subsection{Travel chatbots}

With the ongoing technological advents; the travel planning process has greatly changed (Verani, 2020). Travellers are no longer interested in visiting travel agents to book flights or look for accommodation options (WBB, 2019). For this reason, the travel and tourism industry continues to improve the quality of online services provided and seeks innovative ways to make the online travel planning experience more convenient.

Tourists spend a very long time searching online and comparing prices so that they could find the best travel deals (Peterson, 2015). A tourist has to consider all the available flights and accommodations while bearing in his/her mind both the travel time and cost of the trip (Vieira, 2018).

Tourism websites though useful to tourists, tend to focus on only one type of services (flights, accommodation ... etc.) (WBB, 2019) leaving the tourists stumbling across an array of websites (at least 38 to 40 websites) upon planning their vacation trips and before conducting the actual booking (Howard, 2018; Peterson, 2015) which makes the online travel planning process tiresome and time-consuming (Vieira, 2018).

Since chatbots are ideal for customer-centric businesses (Verani, 2020). Therefore, travel chatbots offer a better alternative (Abu Shawar et al., 2005) that travel and tourism-related businesses can benefit from in the way they manage and engage their customers.

According to Sheffield (2016), travel chatbots can be classified into three different types:

- Travel customer-service chatbots. These are a relatively primitive type of travel chatbots embedded within tourism service providers' websites commonly used to handle customers' inquires and help them through website navigation (e.g. United Airlines' chatbot 'Alex').

- Messaging apps travel chatbots. These travel chatbots are a bit advanced compared to the latter type in terms of interactivity. They are mainly used by travel metasearch engines and OTAs to help users book travel through the messaging apps (e.g. Skyscanner and Expedia Facebook Messenger chatbots). 
- Artificial intelligence travel chatbots. These are virtual travel assistants. Although they also rely on instant messaging apps, they are much more advanced than simple Facebook Messenger bots as they use algorithms to provide users with personalized travel recommendations (e.g. HelloHipmunk chatbot).

\subsection{Millennials}

Strauss and Howe (1991) were the first to introduce the term 'Millennial'. Many terms such as 'Generation Y' (Advertising Age, 1993), 'Baby Boom Echo' (Foot and Stoffman, 1998), 'Nexus generation' (Barnard et al., 1998; Ishak et al., 2019; Ng and Johnson, 2015), 'GenMe', 'GenNext' (Luttrell and McGrath, 2015), 'echo-boomers', and 'dot.com generation' (San et al., 2015) have all been used in reference to the millennial generation. In this study, the term 'Millennials' is used in consistence with recent literature.

Millennials can be defined as individuals born between the 1980s and 2000s (CalvoPorral and Pesqueira-Sanchez, 2019; Gurău, 2012; Miller and Washington, 2011). However, there is still an ongoing debate concerning identifying a precise age-range classification for Gen Y, as experts can't seem to agree on when exactly the generation starts and ends. These arguments resulted in a number of definitions (Evangelu, 2014; Sziva and Zoltay, 2016) which in turn lead to a crossover between the younger Generation Y and the older Generation Z (Skinner et al., 2018). In this study, the adopted time interval is (1980-2000) to be consistent with Egypt's population age groups. Therefore, the research will be focusing on Egyptian Millennials aged between 20 and 39 years old.

\subsubsection{Millennial travellers}

According to IPK International, Millennials accounted for 40 per cent of the global international travel in 2017 (ITB Berlin, 2018). They are the most rapidly growing demographic segment in the tourism market (CBI, 2021) as Millennials tend to travel more frequently (Pendergast, 2009) (an average of 35 days of vacation per year) (Rezdy, 2018) than any other demographic group. Therefore, millennial travellers are considered a powerful growing force that is already reshaping the future of the travel and tourism industry (Rezdy, 2018; Sofronov, 2018).

Technologically speaking, millennial travellers are characterised by the following:

- They are Internet savvy travellers who look for the best travel opportunities and seek out premium services with the best prices so they are keen on doing extensive online information search before the actual trip booking (CBI, 2021; Sofronov, 2018).

- They actively use social media (mostly Facebook, TripAdvisor, Instagram, and YouTube) to gather information about travel destinations (Werenowska and Rzepka, 2020).

- They often use their smartphones to plan their vacation trips, as they prefer making online bookings (flights, hotel reservations ... etc.) via the travel apps available on their mobile phones (ITB Berlin, 2018; Sofronov, 2018). 
- They demand instant, exceptional, and personalized services tailored to their particular needs (Crown Verity, 2015).

To sum it up, Millennials are avid travellers (UNWTO, 2016) who are in constant search of travel information and new destinations (Rezdy, 2018; Sofronov, 2018). Since they are tech-savvy (Richards and Morrill, 2020), they use modern technology to make informed travel-buying decisions (Sofronov, 2018). Therefore, travel chatbots appear as an innovative technological solution that millennial travellers should consider when planning their vacation trips. With the help of these AI-enabled personal travel-planning assistants, they can easily plan their trips, complete bookings, and build personalized itineraries as well.

\subsubsection{Egyptian millennial travellers}

Millennials constitute 31.5 per cent of the Egyptian population (CAPMAS, 2020). Since Millennials represent the current travel consumers (Hamed, 2017), there is a persistent need to uncover their wants and preferences as a target market segment that can drive growth in the Egyptian travel and tourism industry (El Demerdash, 2019).

According to Attallah and El-Mawardy (2018), the majority of the Egyptian Millennials (86.5 per cent) surveyed in their study considered social media and travel apps trustworthy travel information sources when planning their vacation trips. In addition, more than half of the participants (58.8 per cent) preferred online travel bookings.

However, there is still a lack of relevant literature on Egyptian millennial travellers, and in-depth studies concerning their travel purchasing behaviours including travel trends, travel-spending patterns, and travel technology use behaviour are further needed.

\section{Methodology}

To the best of the researcher's knowledge, this is the first study investigating the adoption of travel chatbots among Egyptian Millennials. Accordingly, to gain indepth insights, the study adopted an exploratory research approach.

\subsection{Data collection and sampling}

To answer the research questions, a survey in the form of an online self-administered questionnaire was created using Google Forms. Since the population of the study comprises Egyptian Millennials who are frequent travellers and regularly surf the Internet. The researcher posted the survey on various Egyptian Facebook travel groups. However, the response rate was very low. Therefore, the researcher used convenience sampling where participants ageing between 20 and 39 who met the previous two prerequisites were recruited via social media platforms mainly Facebook and WhatsApp.

A number of 281 responses were received, out of which 40 responses were discarded for various reasons (duplicate responses, respondents were not frequent travellers, did not regularly surf the internet or they didn't fit the age range). Thus, the final sample was comprised of 241 responses. This sample is appropriate for the exploratory nature of the research study (Daniel, 2012). 


\subsection{Questionnaire development}

Structure-wise the survey was composed of 40 items. The first part of the questionnaire aimed to evaluate the participants' past experiences with chatbots. Based on five questions Table 1, it would be determined if the participant has ever been in contact with a chatbot and what is his/her general attitude towards it.

\section{Table 1}

Past experiences with chatbots

\begin{tabular}{|l|c|}
\hline \multicolumn{1}{|c|}{ Question } & Question Type \\
\hline Do you know what a chatbot is? & Yes/No question \\
\hline Have you ever used a chatbot before? & Yes/No question \\
\hline Please specify, what did you use a chatbot for? & CATA* question \\
\hline $\begin{array}{l}\text { In your opinion, what are the main advantages of using } \\
\text { chatbots? }\end{array}$ & CATA question \\
\hline $\begin{array}{l}\text { In your opinion, what are the main disadvantages of using } \\
\text { chatbots? }\end{array}$ & CATA question \\
\hline
\end{tabular}

*CATA: check-all-that-apply.

The second part of the questionnaire (21 items) had the purpose of capturing the motives for using travel chatbots by asking the participant the following question 'What motives you to use travel chatbots?'. To answer, participants were asked to indicate how strongly do they agree or disagree with a number of statements using a five-point Likert scale ranging from (1) 'Strongly disagree' to (5) 'Strongly agree'.

To assess motives for using travel chatbots, the research study adopted existing validated measurement items as follows:

- The four dimensions of motives (productivity, entertainment, social, and Novelty and Curiosity) were mainly adopted from Brandtzaeg and Følstad (2017). The items pertaining to these dimensions were derived from Davis (1989), Papacharissi and Rubin (2000), Moon and Kim (2001), Parra-Lopez et al. (2011), Venkatesh et al. (2012), Luo and Remus (2014), Candela (2018), Rieke (2018), and MeliánGonzález et al. (2021).

- Due to the COVID-19 pandemic situation, the researcher considered perceived fear as a new motive for adopting travel chatbots, and its items were adapted from AlMaroof et al. (2020).

For assessing travel chatbots' perceived risk, two items concerning privacy and AI global risks were adopted from Candela (2018). Similarly, to evaluate participants behavioural intention to use travel chatbots, they were asked to indicate how strongly do they agree or disagree - using a 5-point Likert scale - with five items derived from Moon and Kim (2001), Lee (2009), Parra-Lopez et al. (2011), Venkatesh et al. (2012) and Melián-González et al. (2021).

Finally, seven questions concerning demographic characteristics, travel experience, and internet usage are provided in the last part of the questionnaire to collect participants' profiles. Participants were asked to specify their gender, age group (2029/30-39), level of education, nationality, if they were frequent travellers (yes/no), 
how often do they surf the internet, and what devices do they usually use to connect to the internet.

\subsection{Validity and reliability}

To establish the questionnaire's face validity, a pre-test in the form of a discussion with a group of ten Egyptian Millennials who had previous experience with chatbots was conducted before the main survey. The pre-test aimed to find out if the survey questions are clear and understandable for the participants, how long it takes to answer the questionnaire as well as get useful comments and feedback. As a result, the wording of some statements was adjusted for a better understanding of the questionnaire items.

Afterwards, a pilot study was conducted. Cronbach's alpha was used on the pilot sample $(\mathrm{N}=30)$ to measure the internal consistency of each construct and detect any reliability issues that require modifying the questionnaire before making it available to a larger sample.

The Cronbach's alpha for all the constructs ranged from 0.579 to 0.911 which in turn establishes the reliability of the study instrument as it meets the reliability threshold limit of above 0.5 , as suggested by Nunnally (1978). However, according to Straub et al. (2004), it is suggested that reliability should be equal to or above 0.60 for both exploratory and pilot studies.

Therefore, by excluding Q1 in the entertainment construct 'when I feel lonely', Cronbach's alpha score improved from 0.579 to 0.732 . Similarly, by deleting Q2 in the use intention construct 'When required, I will use travel chatbots', it obtained Cronbach's alpha of 0.886 instead of 0.877 . Cronbach's alpha values for the pilot study are presented in Table 2. The findings of the pre-test and the pilot study showed that the instrument is valid and reliable.

Table 2

Cronbach's alpha values for the pilot study (Cronbach's $\alpha \geq 0.60$ )

\begin{tabular}{|l|c|c|}
\hline \multicolumn{1}{|c|}{ Constructs } & No of items & Cronbach's $\boldsymbol{\alpha}$ \\
\hline Overall Motivation & 20 & 0.909 \\
\hline Productivity & 7 & 0.723 \\
\hline Entertainment & 2 & 0.732 \\
\hline Social & 3 & 0.670 \\
\hline Novelty and Curiosity & 6 & 0.911 \\
\hline Perceived Fear & 2 & 0.843 \\
\hline Perceived Risk & 2 & 0.739 \\
\hline Use Intention & 4 & 0.886 \\
\hline
\end{tabular}

\section{Results}

\subsection{Respondents' profile}

All respondents were Egyptian frequent travellers. With respect to age distribution, old Millennials (30-39) represented 52.4 per cent, while young Millennials (20-29) represented 47.7 per cent. Female respondents (53.9 per cent) outnumbered males who accounted for only 46.1 per cent of total respondents. More than half of the 
respondents (64.3 per cent) held a bachelor's degree, while the rest have completed either their master's degree (20.7 per cent) or doctorate (14.9 per cent). Concerning internet usage, 46.9 per cent of respondents were always online, while 31.1 per cent daily surfed the internet for few hours and 18.7 per cent surfed it several times a day for few minutes. The majority of respondents (83.8 per cent) connected to the internet using their smartphones. Respondents' background characteristics are summarised in Fig. 1 .
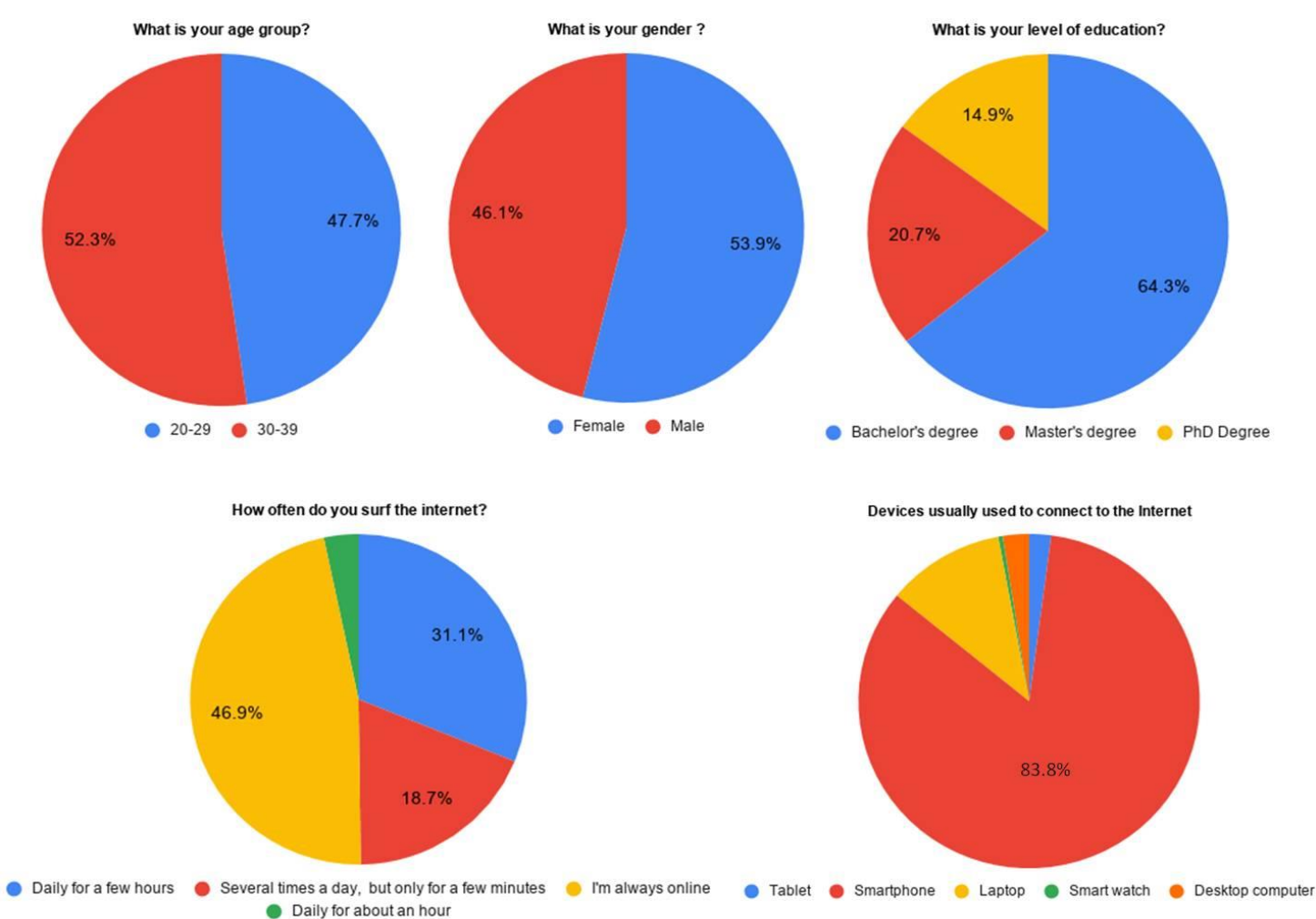

\subsection{Experience with chatbots}

As shown in Fig. 2. the majority of respondents (71.8 per cent) were familiar with the concept of chatbots. However, only 62.7 per cent of respondents had actually used a chatbot before, i.e. more than 30 per cent have never used a chatbot. Chatbots were mainly used for customer service (18 per cent) and online shopping (17.9 per cent). Only 7.3 per cent of respondents have used chatbots for travel bookings.

Most of the respondents' answers concerning the advantages of chatbots referred to productivity, such as convenience (29.3 per cent) and speed (25.8 per cent). On the other hand, the respondents identified the main disadvantages of using chatbots as the preference to communicate with a real person (29.9 per cent), not being understood (17.8 per cent), and concerns about privacy and data security (12.8 per cent) (Fig. 3.). 

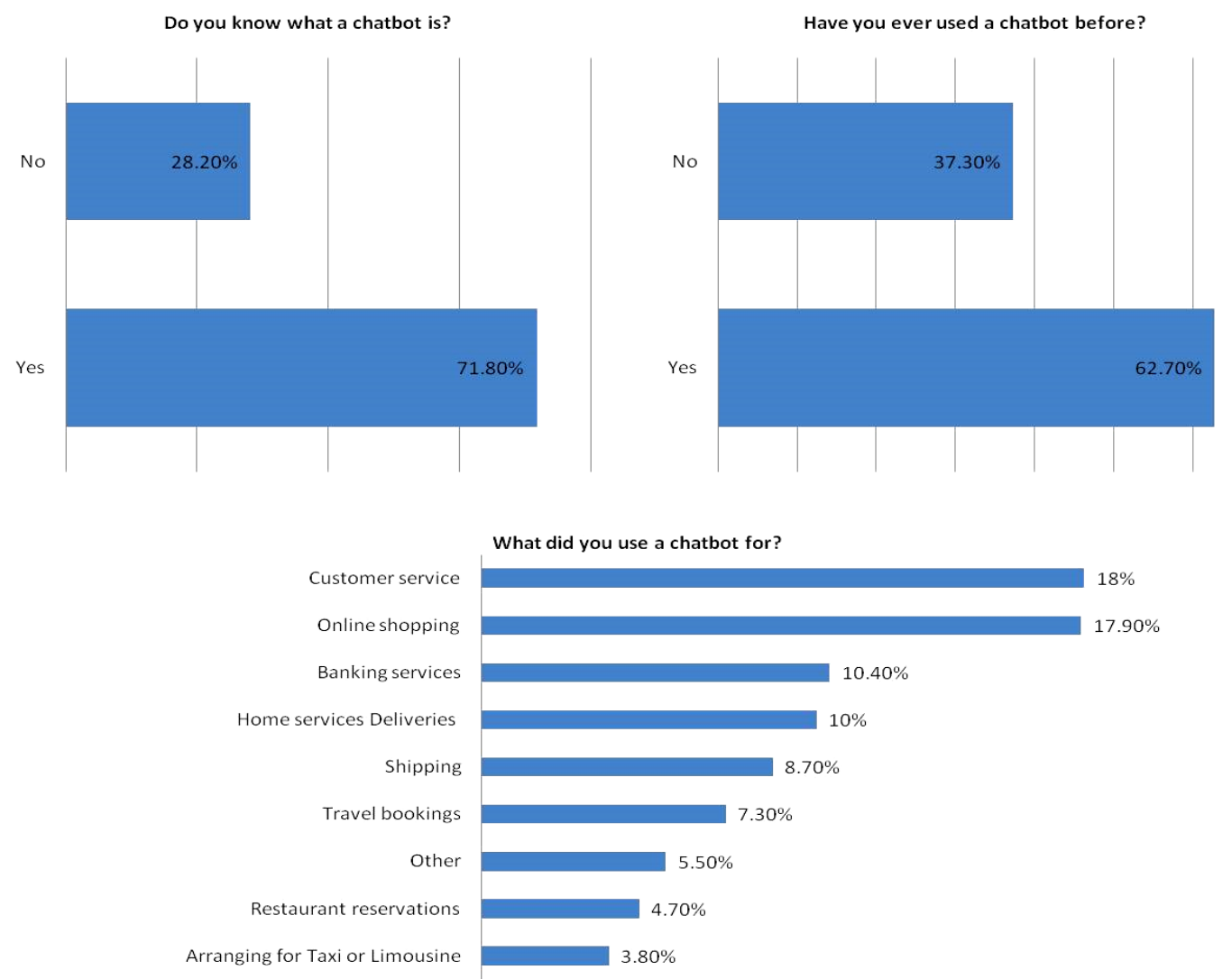

Fig. 2. Past experiences with chatbots

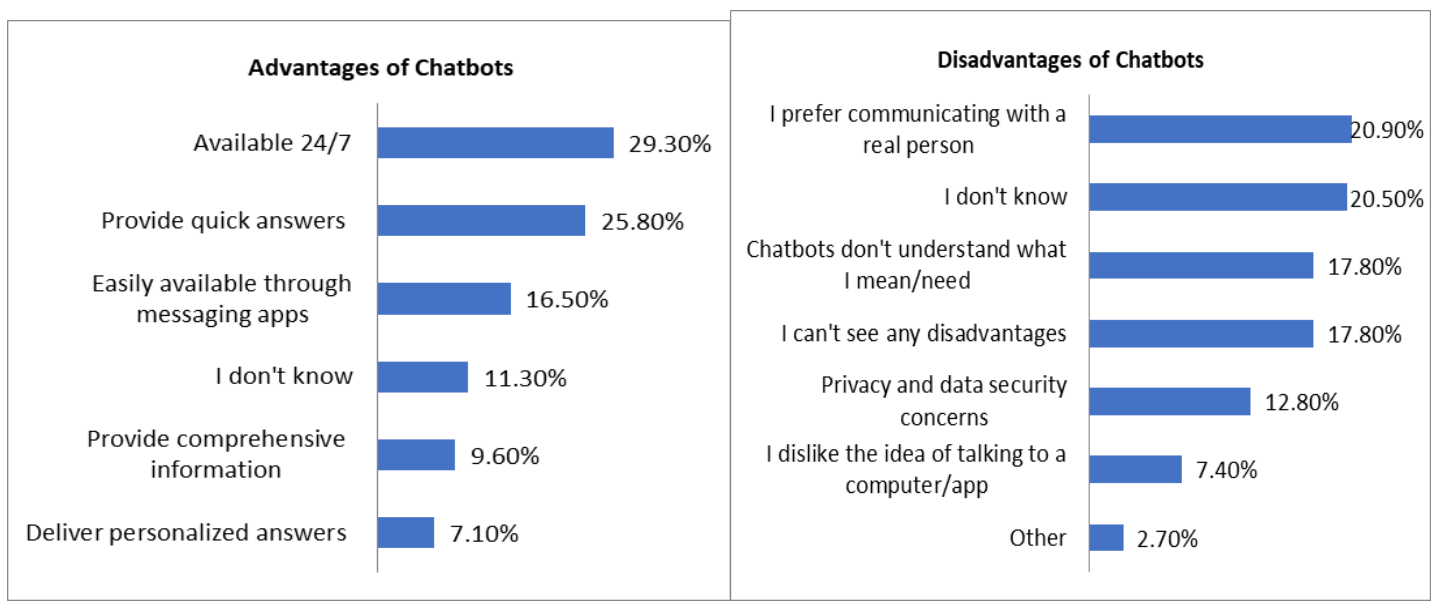

Fig. 3. Advantages and disadvantages of chatbots

\subsection{Travel chatbots motivation}

Regarding the motivations for using travel chatbots, the results show that productivity is the strongest motivation for using travel chatbots displaying the highest value $($ mean $=4.16)$, followed by curiosity $($ mean $=3.87)$ and perceived fear $($ mean $=3.61)$ while social $($ mean $=3.18)$ and entertainment $($ mean $=2.94)$ motivations displayed the lowest values. The responses to the items pertaining to the various motivation dimensions are presented in Table 3. 
Table 4 shows that both chatbot users and non-users had a positive attitude towards the productivity dimension where chatbot users had a 'strongly agree' attitude with a mean value of 4.35 , while non-users had an 'agree' attitude with a mean value of 3.84. Overall, getting quick answers ( 88 per cent) and convenience ( 88 per cent) were the strongest motives for using travel chatbots, followed by obtaining travel information (83 per cent) and usefulness in the Covid-19 pandemic ( 81 per cent).

As previously mentioned, novelty and curiosity ranked second place after productivity. Both chatbot users and non-users had a positive attitude with mean scores of 3.89 and 3.81 respectively (Table 4). Being up-to-date with the latest technological apps $($ mean $=4.07)$ and seeking to explore new technologies $($ mean $=$ 3.95) were the strongest motives in the novelty and curiosity dimension that pushed chatbot users to adopt travel bots while trying something new $($ mean $=3.91)$ and travel chatbots being new and intriguing (mean $=3.88$ ) were the strongest motives that could push non-users to adopt travel chatbots.

Moreover, perceived fear ranked third before both social and entertainment constructs. All respondents had a positive attitude 'agree' towards the importance of using travel chatbot during the COVID-19 pandemic. The majority of the respondents (64 per cent) stated that using travel chatbots reduced or could reduce their fear of the COVID-19 pandemic. Also, more than half of the respondents (60 per cent) either agreed or strongly agreed that travel chatbots provided or could provide them with a chance to escape the COVID-19 pandemic lockdown.

Regarding the last two travel chatbots' motivation dimensions, the general attitude of the respondents towards the social dimension was neutral with a mean value of 3.18 (Table 4). More than half of the respondents strongly disagreed, disagreed, or were neutral concerning the two statements that constitute the social motivation dimension. Similarly, the attitude of the respondents towards the entertainment dimension was neutral with the lowest mean value. Only around one-third (37 per cent) of the respondents showed agreement concerning the three statements that construct the entertainment motivation dimension.

\subsection{Perceived risk}

With regard to risk perception, the respondents showed a neutral response for the two statements concerning travel chatbot perceived risks based on a mean score of 2.97 where 41 per cent of respondents with a mean of 3.00 either agreed or strongly agreed that using travel chatbots is risky in terms of privacy. Similarly, only 39 per cent of the respondents with a mean of 2.94 expressed agreement on travel chatbots being risky in terms of global risks associated with AI. The responses to the items of perceived risk are presented in Table 5.

However, by analysing the attitudes (Table 4) of both chatbot users and non-users, it was noticed that chatbot users' attitude towards perceived risk is 'disagree' with a mean of 2.63 which means they don't perceive chatbots as risky in terms of privacy and AI-related risks while non-users attitude towards perceived risk is 'agree' with a mean of 3.54 which means they perceive chatbots as risky in terms of privacy and AIrelated risks. 
Table 3

Motives for using travel chatbots

\begin{tabular}{|c|c|c|c|c|c|c|c|c|c|c|c|c|}
\hline \multirow{2}{*}{ Motives $($ mean = 3.55) } & \multicolumn{2}{|c|}{$\begin{array}{l}\text { Strongly } \\
\text { Disagree }\end{array}$} & \multicolumn{2}{|c|}{ Disagree } & \multicolumn{2}{|c|}{ Neutral } & \multicolumn{2}{|c|}{ Agree } & \multicolumn{2}{|c|}{$\begin{array}{l}\text { Strongly } \\
\text { Agree }\end{array}$} & \multirow{2}{*}{$\stackrel{\Xi}{\Xi}$} & \multirow{2}{*}{ 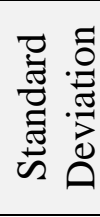 } \\
\hline & 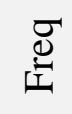 & se & 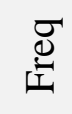 & se & ర્ટ் & $s^{e}$ & す্ৰ & se & 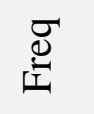 & $s^{2}$ & & \\
\hline \multicolumn{13}{|l|}{ Productivity $($ mean $=4.16)$} \\
\hline to obtain assistance or travel information & 6 & 2 & 5 & 2 & 28 & 12 & 95 & 39 & 107 & 44 & 4.21 & 0.91 \\
\hline to book a (flight, hotel room, limousine... etc.) & 10 & 4 & 24 & 10 & 43 & 18 & 85 & 35 & 79 & 33 & 3.83 & 1.12 \\
\hline to get quick answers & 4 & 2 & 4 & 2 & 20 & 8 & 56 & 23 & 157 & 65 & 4.49 & 0.85 \\
\hline because travel chatbots are easy to use & 4 & 2 & 9 & 4 & 42 & 17 & 81 & 34 & 105 & 44 & 4.14 & 0.95 \\
\hline because I can tailor a travel chatbot to my specific needs & 10 & 4 & 25 & 10 & 60 & 25 & 69 & 29 & 77 & 32 & 3.74 & 1.14 \\
\hline $\begin{array}{l}\text { because travel chatbots are convenient i.e. available } \\
(24 / 7 / 365)\end{array}$ & 3 & 1 & 3 & 1 & 23 & 10 & 70 & 29 & 142 & 59 & 4.43 & 0.81 \\
\hline $\begin{array}{l}\text { because I find using travel chatbots useful during the } \\
\text { Covid-19 pandemic }\end{array}$ & 9 & 4 & 5 & 2 & 32 & 13 & 57 & 24 & 138 & 57 & 4.29 & 1.02 \\
\hline \multicolumn{13}{|l|}{ Entertainment $($ mean $=2.94)$} \\
\hline when I am bored & 53 & 22 & 54 & 22 & 47 & 20 & 57 & 24 & 30 & 12 & 2.82 & 1.35 \\
\hline when travel chatbots have a sense of humor & 30 & 12 & 60 & 25 & 61 & 25 & 64 & 27 & 26 & 11 & 2.98 & 1.20 \\
\hline because travel chatbots are fun and entertaining & 33 & 14 & 48 & 20 & 70 & 29 & 61 & 25 & 29 & 12 & 3.02 & 1.22 \\
\hline \multicolumn{13}{|l|}{ Social $($ mean $=3.18)$} \\
\hline $\begin{array}{l}\text { because I like the sense of talking to someone when I use } \\
\text { travel chatbots }\end{array}$ & 28 & 12 & 28 & 12 & 67 & 28 & 93 & 39 & 25 & 10 & 3.24 & 1.15 \\
\hline to train my conversational skills & 36 & 15 & 36 & 15 & 64 & 27 & 73 & 30 & 32 & 13 & 3.12 & 1.25 \\
\hline \multicolumn{13}{|l|}{ Novelty and Curiosity $($ mean $=3.87)$} \\
\hline to try something new & 6 & 2 & 12 & 5 & 41 & 17 & 121 & 50 & 61 & 25 & 3.91 & 0.92 \\
\hline to test out travel chatbot skills & 11 & 5 & 18 & 7 & 45 & 19 & 112 & 46 & 55 & 23 & 3.76 & 1.03 \\
\hline because travel chatbots are new and intriguing & 7 & 3 & 7 & 3 & 55 & 23 & 107 & 44 & 65 & 27 & 3.90 & 0.93 \\
\hline
\end{tabular}

59 |P a g e 


\begin{tabular}{|c|c|c|c|c|c|c|c|c|c|c|c|c|}
\hline \multirow{2}{*}{ Motives $($ mean = 3.55) } & \multicolumn{2}{|c|}{$\begin{array}{l}\text { Strongly } \\
\text { Disagree }\end{array}$} & \multicolumn{2}{|c|}{ Disagree } & \multicolumn{2}{|c|}{ Neutral } & \multicolumn{2}{|c|}{ Agree } & \multicolumn{2}{|c|}{$\begin{array}{l}\text { Strongly } \\
\text { Agree }\end{array}$} & \multirow{2}{*}{$\sum_{\Sigma}^{\Xi}$} & \multirow{2}{*}{ 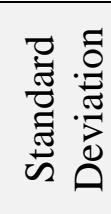 } \\
\hline & 帝 & $s^{e}$ & ర্ষ் & $s^{e}$ & 过 & $a^{2}$ & ర্் & $a^{2}$ & 过 & $2^{2}$ & & \\
\hline out of curiosity & 9 & 4 & 17 & 7 & 59 & 24 & 90 & 37 & 66 & 27 & 3.78 & 1.05 \\
\hline because I seek to explore new technologies & 5 & 2 & 16 & 7 & 51 & 21 & 92 & 38 & 77 & 32 & 3.91 & 0.99 \\
\hline $\begin{array}{l}\text { because I like to be up to date with the latest technological } \\
\text { apps }\end{array}$ & 7 & 3 & 12 & 5 & 53 & 22 & 85 & 35 & 84 & 35 & 3.94 & 1.02 \\
\hline \multicolumn{13}{|l|}{ Perceived Fear $($ mean $=3.61)$} \\
\hline $\begin{array}{l}\text { because using travel chatbots reduces my fear of covid-19 } \\
\text { pandemic }\end{array}$ & 18 & 7 & 23 & 10 & 45 & 19 & 99 & 41 & 56 & 23 & 3.63 & 1.16 \\
\hline $\begin{array}{l}\text { because using travel chatbots provides a chance to be } \\
\text { away from the covid-19 lockdown }\end{array}$ & 16 & 7 & 19 & 8 & 62 & 26 & 94 & 39 & 50 & 21 & 3.59 & 1.10 \\
\hline
\end{tabular}

Table 4

Mean scores and attitudes of study constructs

\begin{tabular}{|l|c|c|c|c|c|c|}
\hline \multirow{2}{*}{ Construct } & \multicolumn{2}{c|}{ Overall Respondents } & \multicolumn{2}{c|}{ Chatbot Users } & \multicolumn{2}{c|}{ Chatbot Non-Users } \\
\cline { 2 - 7 } & Mean & Attitude & Mean & Attitude & Mean & Attitude \\
\hline Productivity & 4.16 & Agree & 4.35 & Strongly Agree & 3.84 & Agree \\
\hline Entertainment & 2.94 & Neutral & 2.94 & Neutral & 2.94 & Neutral \\
\hline Social and Relational & 3.18 & Neutral & 3.14 & Neutral & 3.26 & Neutral \\
\hline Novelty and Curiosity & 3.87 & Agree & 3.89 & Agree & 3.81 & Agree \\
\hline Perceived Fear & 3.61 & Agree & 3.7 & Agree & 3.46 & Agree \\
\hline Risk Perceived & 2.97 & Neutral & 2.64 & Disagree & 3.54 & Agree \\
\hline Intention Use & 4.07 & Agree & 4.23 & Agree & 3.79 & Agree \\
\hline
\end{tabular}




\section{Table 5}

Travel chatbots perceived risks

\begin{tabular}{|c|c|c|c|c|c|c|c|c|c|c|c|c|}
\hline \multirow{2}{*}{$\begin{array}{c}\text { Perceived risk (mean } \\
=2.97 \text { ) }\end{array}$} & \multicolumn{2}{|c|}{\begin{tabular}{|l} 
Strongly \\
Disagree
\end{tabular}} & \multicolumn{2}{|c|}{ Disagree } & \multicolumn{2}{|c|}{ Neutral } & \multicolumn{2}{|c|}{ Agree } & \multicolumn{2}{|c|}{$\begin{array}{r}\text { Strongly } \\
\text { Agree }\end{array}$} & \multirow{2}{*}{ 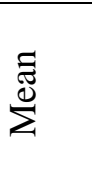 } & \multirow{2}{*}{ 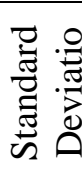 } \\
\hline & ఫ్ర & $a^{e}$ & 赵 & $a^{e}$ & 总 & $b^{2}$ & 离 & $b^{2}$ & ఫ্் & $b^{0}$ & & \\
\hline $\begin{array}{l}\text { I think using travel } \\
\text { chatbots is risky in } \\
\text { terms of privacy and } \\
\text { data security }\end{array}$ & 46 & 19 & 46 & 19 & 51 & 21 & 58 & 24 & 40 & 17 & 3.00 & 1.37 \\
\hline $\begin{array}{l}\text { I think using travel } \\
\text { chatbots is risky in } \\
\text { terms of global risks } \\
\text { associated with AI in the } \\
\text { future }\end{array}$ & 47 & 20 & 47 & 20 & 55 & 23 & 57 & 24 & 35 & 15 & 2.94 & 1.34 \\
\hline
\end{tabular}

\subsection{Use intention}

The general attitude of respondents towards travel chatbots' future use intention was 'agree' with a mean of 4.07 (Table 4). 78 per cent of respondents with a mean of 4.07 intend to use or continue using travel chatbots in the future. The majority of respondents ( 86 per cent) with a mean of 4.27 think that more and more travellers will use travel chatbots in the future. More than half of the respondents ( 68 per cent) with a mean of 3.93 will strongly recommend others to use travel chatbots and finally, 75 per cent of respondents with a mean of 4.00 either agreed or strongly agreed that they will encourage their friends to use travel chatbots for planning their future vacation trips. Both chatbot users and non-users expressed a positive attitude towards chatbot future use intention with mean scores of 4.23 and 3.79 respectively. The responses to the items of use intention are presented in Table 6.

\section{Table 6}

Travel chatbot use intention

\begin{tabular}{|c|c|c|c|c|c|c|c|c|c|c|c|c|}
\hline \multirow[t]{2}{*}{$\begin{array}{c}\text { Use intention }(\text { mean }= \\
4.07)\end{array}$} & \multicolumn{2}{|c|}{$\begin{array}{l}\text { Strongly } \\
\text { Disagree }\end{array}$} & \multicolumn{2}{|c|}{ Disagree } & \multicolumn{2}{|c|}{ Neutral } & \multicolumn{2}{|c|}{ Agree } & \multicolumn{2}{|c|}{$\begin{array}{c}\text { Strongly } \\
\text { Agree }\end{array}$} & \multirow{2}{*}{$\sum^{\varpi \varpi}$} & \multirow{2}{*}{ 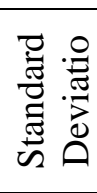 } \\
\hline & \begin{tabular}{|l|}
\multirow{2}{*}{} \\
至
\end{tabular} & $\delta^{\circ}$ & $\overline{\mathscr{V}}$ & $b^{\circ}$ & $\overline{\mathscr{D}}$ & $\delta^{\circ}$ & 可 & 8 & 赹 & se & & \\
\hline $\begin{array}{l}\text { I intend to use or continue } \\
\text { using travel chatbots in the } \\
\text { future }\end{array}$ & 4 & 2 & 7 & 3 & 42 & 17 & 104 & 43 & 84 & 35 & 4.07 & 0.89 \\
\hline $\begin{array}{l}\text { I think that more and more } \\
\text { travellers will use travel } \\
\text { chatbots in the future }\end{array}$ & 2 & 1 & 4 & 2 & 28 & 12 & 99 & 41 & $\begin{array}{c}10 \\
8\end{array}$ & 45 & 4.27 & 0.80 \\
\hline $\begin{array}{l}\text { I will strongly recommend } \\
\text { others to use travel } \\
\text { chatbots }\end{array}$ & 3 & 1 & 7 & 3 & 66 & 27 & 94 & 39 & 71 & 29 & 3.93 & 0.89 \\
\hline $\begin{array}{l}\text { I will encourage my } \\
\text { friends to use travel } \\
\text { chatbots for planning their } \\
\text { future vacation trips }\end{array}$ & 2 & 1 & 10 & 4 & 50 & 21 & 103 & 43 & 76 & 32 & 4.00 & 0.88 \\
\hline
\end{tabular}




\section{Discussion and conclusion}

To conclude, the primary focus of this research study was to identify the main determinants that motivate Egyptian millennial travellers to adopt and use travel chatbots as well as better understand their perceived risks and future use intention. For this purpose, a sample of 241 valid responses was collected and analysed.

Although the majority of respondents knew what a chatbot is, over one-third of them have never used a chatbot. Moreover, only a few respondents have actually used chatbots for the purpose of travel bookings which reflects their little knowledge of travel chatbots in particular.

The analysis of the study findings has shown that the strongest motivation that pushed or could push Egyptian millennial travellers to use travel chatbots is productivity, followed by novelty and curiosity. These findings agreed with the findings of both Candela (2018) and Rieke (2018).

Another key finding is that the entertainment dimension is a marginal motive for using travel chatbots. In the study conducted by Brandtzaeg and Følstad (2017), entertainment was assessed as an important motive for using chatbots; however, this motive did not seem to be of such importance to Egyptian Millennials as it scored the lowest value. These findings are coherent with the findings of Rieke (2018) who reached similar results concerning Portuguese millennial chatbot users.

The study findings also show that the social dimension is the second least motive that pushed or could push Egyptian Millennials to use travel chatbots. These findings partially agree with the findings of Candela (2018). According to Candela (2018), the social dimension is the weakest motivation that pushed or could push Italian consumers to use chatbots. However, with in-depth analysis, the researcher found that more than half of the Italian respondents - who already knew what a chatbot is considered social purposes as a motive before entertainment which agrees with the study at hand.

Furthermore, due to COVID-19 pandemic circumstances, the researcher considered perceived fear as a potential motive for adopting travel chatbots among Egyptian millennial travellers. The analysis of the study findings showed a positive general attitude towards perceived fear as a motive that pushed or could push them to use travel chatbots. Perceived fear ranked $3^{\text {rd }}$ after both productivity and curiosity dimensions, i.e. as a motivation, perceived fear was stronger than the social and entertainment dimensions. The previous findings answer the first research question 'What motivates or could motivate Egyptian millennial travellers to use travel Chatbots?'.

Regarding the second research question 'Do Egyptian millennial travellers trust travel chatbots or perceive them risky?'. the findings showed that on the one hand, respondents who have used chatbots before trusted them and did not perceive them as risky. On the other, those who have never used a chatbot before did not trust them and perceived them as risky in terms of privacy and AI-related risks, which is completely understandable as it is normal for them to be sceptical of a new technology they have never used before. 
Finally, the study findings indicated a positive general attitude towards travel chatbot use intention among Egyptian millennial travellers, which reflects their willingness to adopt and use travel chatbots in the future. Thus, answering the last research question 'Are Egyptian millennial travellers willing to adopt and use travel chatbots in the future?'.

\section{Limitations and future work}

This exploratory study tried to examine the attitude towards travel chatbots adoption with regard to the motives of Egyptian millennial travellers. For this reason, a study with a larger sample, more representative of the population should be considered such that the study results could be further validated. Moreover, other segments of the population could be investigated. For example, millennial travellers' attitudes towards travel chatbots could be compared to those of Gen $\mathrm{Z}$ travellers. Comparative studies could also be conducted to explore the travel chatbot motivation of millennial travellers from similar cultures.

Since this research study focused on evaluating the attitude of both millennial travellers who already used a chatbot as well as those who never used a chatbot before, therefore, future research should focus more on studying Egyptian millennial travellers who have already used a chatbot before. This would help in getting deeper insights into the other motives that pushed them to use travel chatbots beyond the ones discussed in this study.

Moreover, future research could focus on evaluating the usability of travel chatbots and measuring users' satisfaction. It is also possible to conduct in-depth interviews with different businesses that have already adopted chatbots as a tool in their marketing strategies to get more insights on how travel and tourism businesses in Egypt can benefit from chatbots technology so that they could deliver high-quality online travel experiences.

\section{References}

Abu Shawar, B.A., Atwell, E. and Roberts, A. (2005), "FAQChat as an information retrieval system", Human Language Technologies as a Challenge. Proceedings of the 2nd Language and Technology Conference, Poznań, Poland, pp. 274-278.

Adroit Market Research. (2020), "Conversational AI Platform Market by Technology, Type, Application, and by Region, Global Forecast 2018 to 2025”, available at: https://www.adroitmarketresearch.com/contacts/request-sample/1296 (accessed 17 October 2020).

Advertising Age. (1993), "Generation Y”, Advertising Age, Vol. 64 No. 36, p. 16.

Al-Maroof, R.S., Salloum, S.A., Hassanien, A.E. and Shaalan, K. (2020), "Fear from COVID-19 and technology adoption: the impact of Google Meet during Coronavirus pandemic", Interactive Learning Environments, pp. 1-16.

Attallah, N.F. and El-Mawardy, G. (2018), "The Reciprocal Relationship Between Generation Y (Millennials) and Creative Tourism With Application on Egypt", Journal of Tourism Research, Vol. 20, pp. 66-77. 
Barnard, R., Cosgrove, D. and Welsh, J. (1998), Chips \& Pop: Decoding the Nexus Generation., Malcolm Lester Books, Toronto, CA.

Battestini, A., Setlur, V. and Sohn, T. (2010), "A large scale study of text-messaging use", Proceedings of the 12th International Conference on Human Computer Interaction with Mobile Devices and Services - MobileHCI '10, ACM Press, New York, New York, USA, pp. 229-238.

Brandtzaeg, P.B. and Følstad, A. (2017), "Why people use chatbots", in Kompatsiaris, I. and Al., E. (Eds.), Lecture Notes in Computer Science, Vol. 10673 LNCS, Springer International Publishing, pp. 377-392.

Calp, M.H. (2020), "The Role of Artificial Intelligence Within the Scope of Digital Transformation in Enterprises", in Ekren, G., Erkollar, A. and Oberer, B. (Eds.), Advanced MIS and Digital Transformation for Increased Creativity and Innovation in Business, IGI Global, Hershey, PA, pp. 122-146.

Calvo-Porral, C. and Pesqueira-Sanchez, R. (2019), "Generational differences in technology behaviour: comparing millennials and Generation X", Kybernetes, Vol. 49 No. 11, pp. 2755-2772.

Candela, E. (2018), Consumers 'Perception and Attitude towards Chatbots Adoption. A Focus on the Italian, MSc.Thesis., Aalborg University.

CAPMAS. (2020), "Statistical Yearbook: Population chapter (in Arabic)", available at: https://capmas.gov.eg/Pages/Publications.aspx?page_id=5104\&Year=23562 (accessed 21 October 2020).

CBI. (2021), "The European market potential for Generation Y tourism", available at: https://www.cbi.eu/market-information/tourism/generation-y-tourism/marketpotential (accessed 29 January 2021).

Crown Verity. (2015), "The Millennials and Catering in the Hospitality and Travel Industry", available at: https://www.crownverity.com/blog/the-millennials-andcatering-in-the-hospitality-and-travel-industry (accessed 22 November 2020).

Daniel, J. (2012), Sampling Essentials: Practical Guidelines for Making Sampling Choices, Sampling Essentials: Practical Guidelines for Making Sampling Choices, SAGE Publications, Inc., California, USA, available at:https://doi.org/10.4135/9781452272047.

Davis, F.D. (1989), "Perceived Usefulness, Perceived Ease of Use, and User Acceptance of Information Technology", MIS Quarterly, Vol. 13 No. 3, pp. 319-340.

Dell Technologies. (2020), "Measuring digital transformation progress around the world", available at: https:/www.delltechnologies.com/eneg/perspectives/digital-transformation-index.htm\# scroll=off $\quad$ (accessed 17 October 2020).

Deloitte. (2020), “COVID-19: The upskilling imperative - Building a future-ready workforce for the AI age", available at: https://www2.deloitte.com/content/dam/Deloitte/ca/Documents/ deloitteanalytics/ca-covid19-upskilling-EN-AODA.pdf (accessed 17 October 2020). 
El Demerdash, J.M. (2019), “Exploring Millennials' Perception of Greening Hotels in Egypt", Journal of the Faculty of Tourism and Hotels, Alexandria University (JFTH), Vol. 16 No. 1, pp. 88-101.

Evangelu, J.E. (2014), "Generation $Y$ and the reality of her motivation in their personal and professional development", Czech Hospitality \& Tourism Papers., Vol. 10 No. 22, pp. 59-66.

Foot, D.K. and Stoffman, D. (1998), Boom, Bust \& Echo 2000: Profiting from the Demographic Shift in the New Millennium, Macfarlane Walter and Ross, Toronto, CA.

Frankenfield, J. (2020), "Chatbot Definition", available at: https://www.investopedia.com/terms/c/chatbot.asp (accessed 10 November 2020).

Gupta, K. (2020), "Human interactions go digital in a COVID world: Introducing the Roadmap to Building Consumer Trust", available at: https://www.twilio.com/the-current/human-interactions-digital-covid--buildingconsumer-trust (accessed 27 June 2021).

Gurău, C. (2012), “A life-stage analysis of consumer loyalty profile: Comparing Generation X and Millennial consumers", Journal of Consumer Marketing, Vol. 29 No. 2, pp. 103-113.

Hamed, H.M. (2017), "Marketing Destinations to Millennials: Examining the Compatibility between the Destination Marketing Organization Website and the Millennial Tourist Prospects", Journal of Tourism and Recreation, Vol. 3 No. 1, pp. $1-20$.

Howard, J. (2018), "Why Chatbots meet the needs of today's Destinations", available at: http://wheretobot.com/book/destination-marketing-with-chatbots/ (accessed 25 November 2020).

Howe, N. (2015), "Why Millennials Are Texting More And Talking Less", Forbes, 15 July, available at: https://www.forbes.com/sites/neilhowe/2015/07/15/whymillennials-are-texting-more-and-talking-less/\#383a47bd5975 (accessed 21 October 2020).

IFS. (2020), "Transformation investment in 2020 and beyond: Factors that will impact the success or failure of technology investments in the post-pandemic era", available at: https://www.ifs.com/us/sitecore/medialibrary/assets/2020/06/29/global-pr-survey-digital-transformation-investment-in2020-and-beyond (accessed 17 October 2020).

Io, H.N. and Lee, C.B. (2018), "Chatbots and conversational agents: A bibliometric analysis", IEEE International Conference on Industrial Engineering and Engineering Management, Vol. 2017-Decem, Singapore, pp. 215-219.

Ishak, N.A.B.M., Abidin, N.B. and Rajadurai, J. (2019), "Nexus Generation Job Creators: A Review of Generational Attributes and Opportunities", Journal of Southeast Asian Research, Vol. 2019, pp. 1-12.

ITB Berlin. (2018), "What are the trends to look out for?", available at: 
https://www.itb-

berlin.de/media/itbk/itbk_dl_all/ITB_2019_WTTR_Factsheets_ALLE_Web_4.p df (accessed 25 November 2020).

Lee, M.C. (2009), "Factors influencing the adoption of internet banking: An integration of TAM and TPB with perceived risk and perceived benefit", Electronic Commerce Research and Applications, Vol. 8 No. 3, pp. 130-141.

Lund, J. (2020), "How Customer Experience Drives Digital Transformation", available at: https://www.superoffice.com/blog/digital-transformation/ (accessed 17 October 2020).

Luo, M.M. and Remus, W. (2014), "Uses and gratifications and acceptance of Webbased information services: An integrated model", Computers in Human Behavior, Vol. 38, pp. 281-295.

Luttrell, R. and McGrath, K. (2015), Millennial Mindset: Unravelling Fact from Fiction, Rowman and Littlefield, London, UK.

Malhotra, Y., Galletta, D.F. and Kirsch, L.J. (2008), "How Endogenous Motivations Influence User Intentions: Beyond the Dichotomy of Extrinsic and Intrinsic User Motivations", Journal of Management Information Systems, Vol. 25 No. 1, pp. 267-300.

Melián-González, S., Gutiérrez-Taño, D. and Bulchand-Gidumal, J. (2021), "Predicting the intentions to use chatbots for travel and tourism", Current Issues in Tourism, Vol. 24 No. 2, pp. 192-210.

Miller, R.K. and Washington, K. (2011), Consumer Behavior: Millennial Consumers, Consumer Behavior, Richard K. Miller and Associates, Loganville, GA.

Moneim, D. (2020), “Arabic Chatbots witnesses surge in H1 2020 amid COVID-19 crisis: $\quad 13$ Jeport", June, available http://english.ahram.org.eg/News/372039.aspx.

Moon, J.W. and Kim, Y.G. (2001), "Extending the TAM for a World-Wide-Web context", Information and Management, Vol. 38 No. 4, pp. 217-230.

Ng, E.S.W. and Johnson, J.M. (2015), "Millennials: who are they, how are they different, and why should we care?", in Burke, R.J., Cooper, C. and Antoniou, A. (Eds.), The Multi-Generational and Aging Workforce, Edward Elgar Publishing, Cheltenham, UK, pp. 121-137.

Papacharissi, Z. and Rubin, A.M. (2000), "Predictors of internet use", Journal of Broadcasting and Electronic Media, Vol. 44 No. 2, pp. 175-196.

Parra-Lopez, E., Bulchand-Gidumal, J. and Armas, R.J.D. (2011), "Intentions to use social media in organizing and taking vacation trips", Computers in Human Behavior, Vol. 27 No. 2, available at:https://doi.org/10.1016/j.chb.2010.05.022.

Pendergast, D. (2009), "Getting to know the Y generation", in Benckendorff, P., Moscardo, G. and Pendergast, D. (Eds.), Tourism and Generation Y, CAB International, UK, pp. 1-15.

Peterson, B. (2015), “Consumers Visit 38 Sites Before Booking, Expedia Says”, 
available at: http://www.travelmarketreport.com/articles/Consumers-Visit-38Sites-Before-Booking-Expedia-Says (accessed 25 November 2020).

Relx. (2020), "RELX Emerging Tech Executive Report 2020", available at: https://stories.relx.com/relx-emerging-tech-2020/index.html (accessed 16 October 2020).

Reports and Data. (2019), "Chatbot Market Analysis, By Platform (Web-Based, Mobile Based) By Type (Software and Services) By Industry Verticals (BFSI, Retail, \& Others) By End User, By Application and By Region, Forecasts to 2026", available at: https:/www.reportsanddata.com/report-detail/chatbotmarket (accessed 17 October 2020).

Rezdy. (2018), "Millennials: An In-depth Look into the Travel Segment", available at: https://www.rezdy.com/blog/millennials-depth-look-travel-segmentinfographic/ (accessed 22 November 2020).

Richards, G. and Morrill, W. (2020), "Motivations of global Millennial travelers", Revista Brasileira de Pesquisa Em Turismo, Vol. 14 No. 1, pp. 126-139.

Rieke, T.D. (2018), The Relationship between Motives for Using a Chatbot and Satisfaction with Chatbot Characteristics in the Portuguese Millennial Population: An Exploratory Study, MSc.Thesis., Faculty of Economics, University of Porto.

Rodríguez, A. (2020), "The chatbot revolution", available at: https://www.belatrixsf.com/ whitepapers/the-chatbot-revolution/ (accessed 17 January 2021).

San, L.Y., Omar, A. and Thurasamy, R. (2015), "Online Purchase: A Study of Generation Y in Malaysia”, International Journal of Business and Management, Vol. 10 No. 6, pp. 1-7.

Sharma, R. (2020), "The impact of COVID-19 on AI adoption", available at: https://www.peoplemattersglobal.com/blog/hr-technology/the-impact-of-covid19-on-ai-adoption-26180 (accessed 16 October 2020).

Sheffield, J. (2016), "The Ultimate Travel Bot List", available at: https://www.30secondstofly.com/ai-software/ultimate-travel-bot-list (accessed 25 November 2020).

Skinner, H., Sarpong, D. and White, G.R.T. (2018), "Meeting the needs of the Millennials and Generation Z: gamification in tourism through geocaching", Journal of Tourism Futures, Vol. 4 No. 1, pp. 93-104.

Sofronov, B. (2018), "Millennials: a New Trend for the Tourism Industry", Annals of Spiru Haret University. Economic Series, Vol. 18 No. 3, pp. 109-122.

Strauss, W. and Howe, N. (1991), Generations: The History of America's Future 1594-2069, William Morrow and Company Inc., New York, NY.

Sziva, I. and Zoltay, R. (2016), "How attractive can Cultural Landscapes be for Generation Y?", Almatourism - Journal of Tourism, Culture and Territorial Development, Vol. 7 No. 14, pp. 1-16. 
UNWTO. (2016), "The Power of Youth Travel", available at: https://www.wysetc.org/wp-content/uploads/2016/03/Global-Report_Power-ofYouth-Travel_2016.pdf (accessed 21 October 2020).

Valtolina, S., Barricelli, B.R., Gaetano, S. Di and Diliberto, P. (2018), "Chatbots and conversational interfaces: Three domains of use", CEUR Workshop Proceedings, Vol. 2101, pp. 62-70.

Venkatesh, V., Thong, J.Y.L. and Xu, X. (2012), "Consumer acceptance and use of information technology: Extending the unified theory of acceptance and use of technology", MIS Quarterly: Management Information Systems, Vol. 36 No. 1, pp. 157-178.

Verani, E. (2020), "Chatbots for the Tourism Industry, a Multi-Faceted Benefit", available at: https://www.inbenta.com/en/blog/chatbot-tourism-industry/ (accessed 25 November 2020).

Vieira, G.L. (2018), Trip-Planning Optimization: Minimizing Cost and Travel Time in Itineraries with Multiple Destinations, MSc.Thesis., School of Engineering, Federal University of Minas Gerais.

Waldron, T. and Wetherbe, J. (2020), "Ensure That Your Customer Relationships Outlast Coronavirus", available at: https://hbr.org/2020/04/ensure-that-yourcustomer-relationships-outlast-coronavirus (accessed 27 June 2021).

WBB. (2019), "How Chatbots are revolutionising the Travel and Tourism Industry", Tramshed Tech, Cardiff.

Werenowska, A. and Rzepka, M. (2020), "The role of social media in generation Y travel decision-making process (case study in Poland)", Information, Vol. 11 No. 8, available at:https://doi.org/10.3390/INFO11080396. 


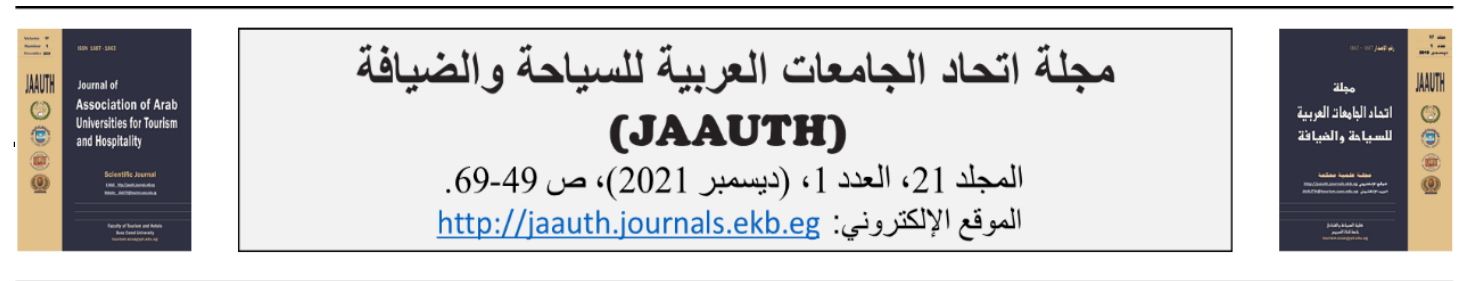

استعداد مسافري جيل الألفية المصري لتبني واستخدام روبوتات الاردشة التفاعلية للسفر: دراسة استكثافية

$$
\text { رضوي علي حامد }
$$

قسم الدراسات السياحية، كلية السياحة والفنادق، جامعة الإسكندرية

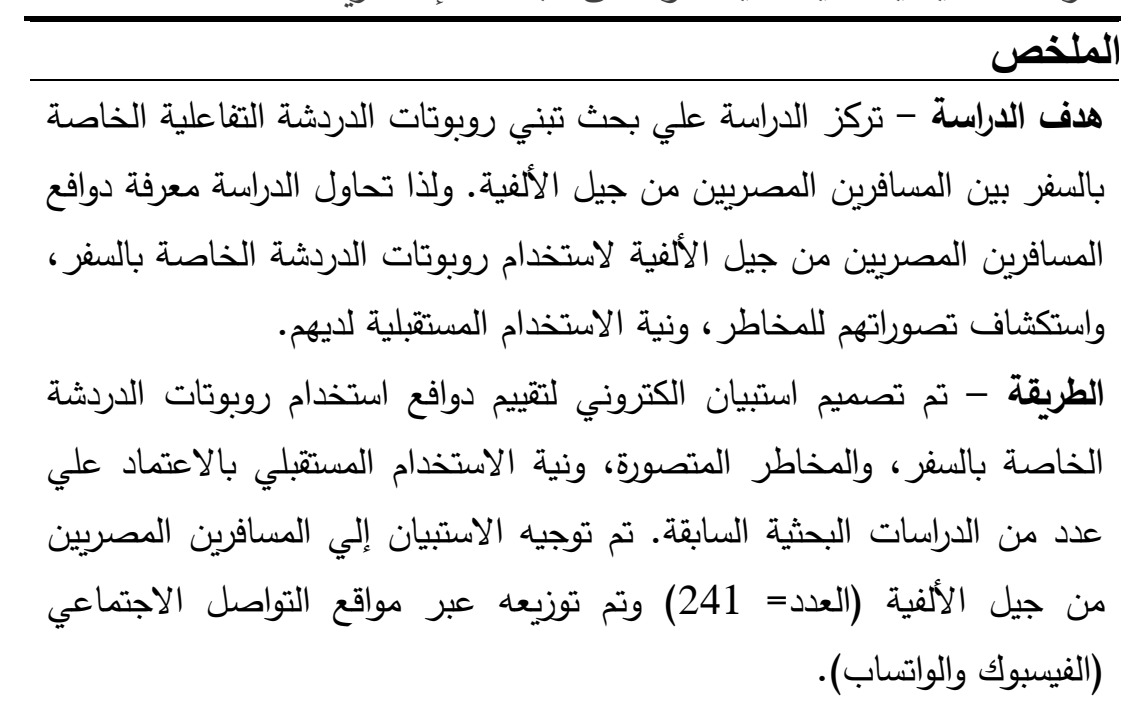

النتائج - لقد كان الدافعان الأكثر قوه لتبني روبوتات الدابنات الدردة للسفر بين

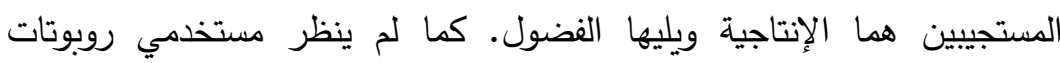

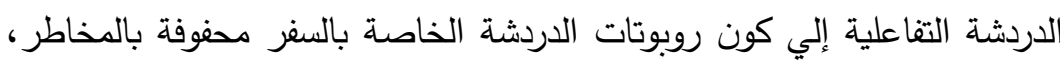

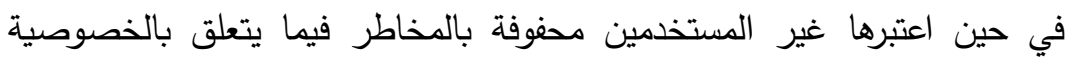
والمخاطر العالمية المرتبطة بالذكاء الاصطناعي.

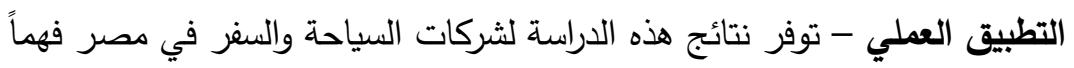

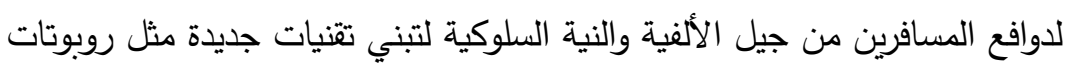

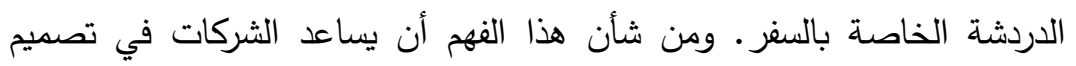
وتقديم تجارب سياحية عبر الانترنت عالية الجودة لعملائها.

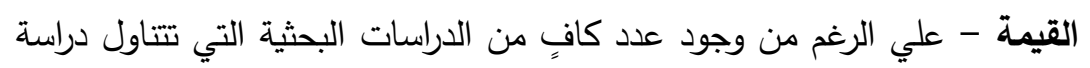

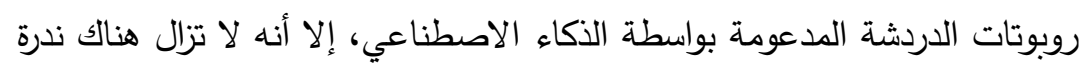

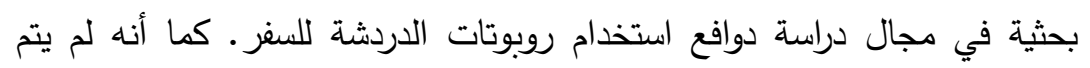

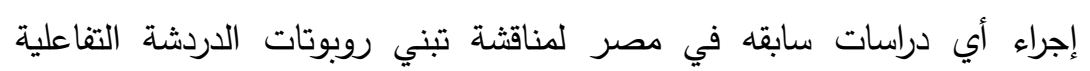

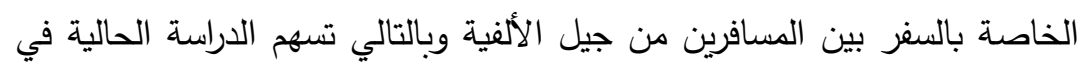
فهم سلوك استخدام تكنولوجيا السفر لاي جيل الألفية المصري.

\section{(JAAUTH)}

المجلد 21، العدد 1، (2021 (2)

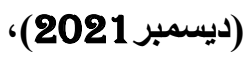

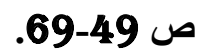

